\title{
Cloning and Expression of the pepD Gene of Escherichia coli
}

\author{
By JÜRGEN KLEIN, BERNHARD HENRICH* AND ROLAND PLAPP \\ Fachbereich Biologie, Abteilung Mikrobiologie, Universität Kaiserslautern, Postfach 3049, \\ D-6750 Kaiserslautern, FRG
}

(Received 13 February 1986; revised 22 March 1986)

\begin{abstract}
Peptidase D of Escherichia coli, cleaving the unusual dipeptide carnosine, was found to be encoded by the ColE1 hybrid plasmid pLC44-11. From this plasmid the pepD gene was subcloned into small vectors. As shown by successive reduction of the flanking sequences of genomic DNA, the order of genes in the region at $6 \mathrm{~min}$ of the E. coli $\mathrm{K} 12 \mathrm{map}$ is phoE, pepD, in the clockwise orientation. Insertional inactivation of the pepD gene and expression of recombinant plasmids in maxicells allowed the identification of the pepD product as a $52 \mathrm{kDa}$ protein. Comparison with the $100 \mathrm{kDa}$ protein molecular mass determined by gel filtration suggests that active peptidase $D$ is probably a dimer.
\end{abstract}

\section{INTRODUCTION}

The presence of various peptidases in Escherichia coli and Salmonella typhimurium (Sussman \& Gilvarg, 1971) is required for the utilization of exogenously supplied peptides (Simmonds \& Fruton, 1949; Gutnick et al., 1969), as well as for the catabolism of intracellular proteins, particularly during starvation of the cells (Pine, 1972; Yen et al., 1980). Peptidases are also involved in the removal of $\mathrm{N}$-terminal methionine from nascent polypeptide chains (Livingston \& Leder, 1969), in the processing of secretory proteins (Blobel \& Dobberstein, 1975) and in the breakdown of abnormal proteins (Miller \& Green, 1981).

As shown by the isolation and characterization of mutant strains, E. coli possesses at least five different peptidases, denoted A, B, D, N and Q, with partly overlapping substrate specificities (Miller \& Schwartz, 1978). This pattern of peptide-degrading activities is similar to that of the closely related organism S. typhimurium (Miller \& Mackinnon, 1974; Miller, 1975a). One of these enzymes, peptidase $\mathrm{D}$, which is active only on dipeptides, was found to be the only peptidase of $S$. typhimurium that cleaved the unusual dipeptide carnosine ( $\beta$-alanyl-L-histidine) (Kirsh et al., 1978). The corresponding gene maps at the 6 min position on the circular map of the $S$. typhimurium genome (Miller, 1975b).

In order to facilitate a more detailed genetic, biochemical and physiological characterization of peptidase D, we cloned the pepD gene of $E$. coli. In this communication we report the detection of pepD in a plasmid library, its subcloning into small vectors and its expression in a maxicell system.

\section{METHODS}

Bacteria, plasmids and phage. E. coli CM17 (Miller \& Schwartz, 1978) was obtained from C. G. Miller, Case Western Reserve University, Cleveland, USA, and strain AB1133 (Howard-Flanders et al., 1966) was from B. Bachmann, E. coli Genetic Stock Center, New Haven, USA. Strain NK5526 [hisG::Tn10 IN(rrnD-rrnE)1] was provided by N. Kleckner, Harvard, Cambridge, USA, and strain CSR603 (Sancar \& Rupert, 1978) was from M. Jackson, Leicester University, UK. Strains PC2086 [thr leu $\Delta$ (gpt-proA) his thi argE purH lacY galK xyl ara mtl tsx rpsL supE] and PC1324 (Low, 1972) as well as the Clarke-Carbon plasmids pLC25-25, pLC32-46, pLC40-18 and pLC44-11 (Clarke \& Carbon, 1976) were obtained from the Phabagen Collection, Utrecht, The Netherlands. Plasmid pBR322 (Bolivar et al., 1977) was from Boehringer Mannheim, the vector pUC18 (Norrander et al., 1983) was obtained from U. Rüther, European Molecular Biology Laboratories, Heidelberg, FRG, and plasmid pUC4K (Vieira \& Messing, 1982) was purchased from Pharmacia. The transducing phage P1CMclr100 (Rosner, 1972) was provided by $\mathrm{R}$. Rosner, National Institutes of Health, Bethesda, USA. 
Growth conditions. Cells were grown in LB medium, containing $10 \mathrm{~g}$ tryptone, $5 \mathrm{~g}$ yeast extract and $5 \mathrm{~g} \mathrm{NaCl}$ per litre, or in Davis minimal medium (Davis \& Mingioli, 1950), supplemented with the required amino acids at a concentration of $50 \mu \mathrm{g} \mathrm{ml}^{-1}$. Antibiotics used were ampicillin $\left(100 \mu \mathrm{g} \mathrm{ml}^{-1}\right)$, kanamycin $\left(40 \mu \mathrm{g} \mathrm{ml}^{-1}\right)$ and tetracycline $\left(12 \mu \mathrm{g} \mathrm{ml}^{-1}\right.$ in the case of plasmid-encoded resistance or $30 \mu \mathrm{g} \mathrm{ml}^{-1}$ in the case of Tn 10 -encoded resistance).

Construction of strain UK61. The hisG : :Tn10 marker of strain NK5526 was transferred to the pepD strain CM17 by use of the transducing phage PlCMclr100 according to the method of Rosner (1972). Transductants which had simultaneously acquired resistance to tetracycline and auxotrophy for histidine were named UK61.

Assay of peptidase D activity. Peptidase D was assayed in sonic extracts of exponentially growing cells. Free histidine released from carnosine (Bachem) was determined fluorimetrically as described by Kirch et al. (1978).

Recombinant DNA techniques. Small scale preparations of plasmid DNA and isolation of restriction fragments from polyacrylamide gels were done by the methods of Maniatis et al. (1982). Restriction endonucleases and T4 DNA ligase (Boehringer Mannheim) were used as recommended by the supplier. Gel electrophoresis of DNA, and preparation and transformation of competent cells, were done as described previously (Henrich et al., 1982).

Protein labelling in maxicells. CSR603 cells transformed with the appropriate plasmids were UV-irradiated, labelled with $\left.{ }^{35} \mathrm{~S}\right] \mathrm{methionine}\left(1110 \mathrm{Ci} \mathrm{mmol}^{-1}, 41 \cdot 1 \mathrm{TBq} \mathrm{mmol}{ }^{-1}\right)(\mathrm{New}$ England Nuclear) and processed for gel electrophoresis essentially as described by Sancar et al. (1979). Following irradiation, D-cycloserine $\left(100 \mu \mathrm{g} \mathrm{ml}^{-1}\right.$ final concentration) was added to the suspension during a $20 \mathrm{~h}$ incubation in order to prevent overgrowth of surviving cells. Total lysates were subjected to $12 \%(\mathrm{w} / \mathrm{v})$ SDS-PAGE at $150 \mathrm{~V}$ for $15 \mathrm{~h}$ using the discontinuous buffer system of Laemmli (1970). Labelled proteins were visualized by autoradiography of vacuum-dried gels.

Gel filtration of peptidase $D$. For the preparation of a crude cell extract, strain PC1324, which carries the pep $D^{+}$ gene not only on the chromosome but also on the $F^{\prime} 104$ plasmid, was used. Cells from 2 litres of an overnight culture of strain PC1324 in supplemented minimal medium were collected by centrifugation, washed twice with $5 \mathrm{mM}$-Tris/ $\mathrm{HCl}, \mathrm{pH} 7 \cdot 5$, resuspended in $10 \mathrm{ml}$ of the same buffer and subsequently disrupted by ultrasonication. Debris and ribosomes were removed by ultracentrifugation at $100000 \mathrm{~g}$ and $4{ }^{\circ} \mathrm{C}$ for $1 \mathrm{~h}$. A sample of the supernatant containing $40 \mathrm{mg}$ protein was mixed with $5 \mathrm{mg}$ of each of the marker proteins (egg white lysozyme and horseradish peroxidase) and then applied to a column $(2.5 \times 100 \mathrm{~cm})$ of Ultrogel AcA44 (LKB) equilibrated with $5 \mathrm{~mm}$-Tris/ $\mathrm{HCl}, \mathrm{pH} \mathrm{7.5}$. Gel filtration was done at $8{ }^{\circ} \mathrm{C}$ with a flow rate of $0.4 \mathrm{ml} \mathrm{min}{ }^{-1} ; 2 \mathrm{ml}$ fractions were collected.

To calibrate the column, the activities of different marker enzymes were determined. Peptidase $N(87 \mathrm{kDa})$ and cyclic phosphodiesterase $(63 \mathrm{kDa})$, intrinsic proteins of $E$. coli, were assayed in the presence of the chromogenic substrates L-alanyl-p-nitroanilide (Lazdunski et al., 1975) and bis-p-nitrophenyl phosphate (Anraku, 1964), respectively. Lysozyme (14 kDa) was detected by its lytic action on Micrococcus luteus (Shugar, 1952), and peroxidase $(40 \mathrm{kDa})$ was monitored photometrically by the method of Pütter (1970).

\section{RESULTS AND DISCUSSION}

\section{Identification of the pepD gene in the Clarke-Carbon bank}

According to the genetic map of the E. coli chromosome given by Bachmann (1983), the pepD gene is located between min 5 and 6 . However, its precise position with respect to the adjacent genes has not been determined. Therefore the well selectable marker proBA, mapping at min 5.9, was chosen to search for plasmids of the Clarke-Carbon library (Clarke \& Carbon, 1976) which were likely to carry the pepD gene.

Four plasmids, pLC25-25, pLC32-46, pLC40-18 and pLC44-11, that are known to contain the proBA locus (Hayzer \& Leisinger, 1980) were introduced into strain CM17 carrying a proBA pep $D$ deletion, and transformants were selected by their proline-independence. Fluorimetric determination of peptidase $\mathrm{D}$ activity in cell free extracts of the transformants revealed that the only plasmid bearing a functional pepD gene was pLC44-11. This plasmid, $29.7 \mathrm{~kb}$ in size, was shown to code for at least eight polypeptides with distinct electrophoretic mobilities (Neidhardt et al., 1983), and it had already served as a source for the cloning of the $E$. coli genes phoE (Tommassen et al., 1982) and proBA (Hayzer, 1983). Therefore the location of these genes as well as the positions of some restriction sites in plasmid pLC44-11 are known (Fig. 1).

In order to locate the pepD gene on the pLC44-11 map, the three fragments generated by $S a$ II cleavage of the plasmid were cloned into the SalI site of pBR322 (Bolivar et al., 1977). Fluorimetric assays of peptidase $D$ showed that none of the three types of recombinant plasmids which were detected in tetracycline-sensitive transformants of strain CM17 contained a functional pepD gene. This suggested that the pepD gene itself or its promoter had been 


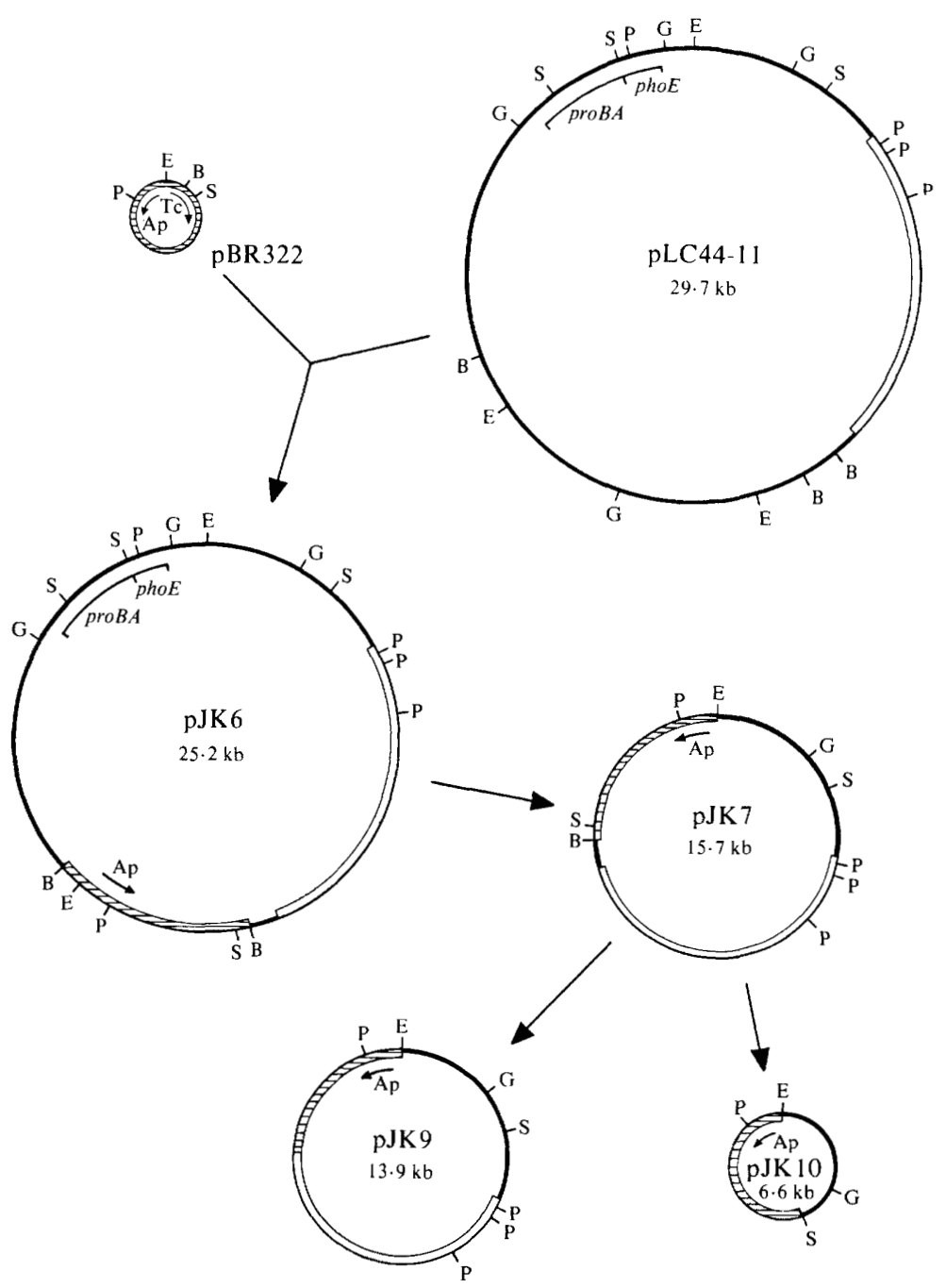

Fig. 1. Subcloning of the pepD gene of $E$. coli from pLC44-11. The fragments generated by BamHI digestion of plasmid pLC44-11 were ligated with BamHI-linearized pBR322; strain UK61 was transformed with the mixture. All of the carnosine-utilizing clones obtained were found to contain the largest $(20.9 \mathrm{~kb})$ BamHI fragment in a unique orientation. In the recombinant plasmid pJK6 a $9.5 \mathrm{~kb}$ $E c o$ RI fragment, containing the phoE and $p r o B A$ genes, was deleted by EcoRI digestion and religation. The resulting plasmid, pJK 7, was still able to confer peptidase D activity to strain UK61. In contrast, elimination of the $9.1 \mathrm{~kb} \mathrm{Sall}$ fragment from $\mathrm{pJK} 7$, giving rise to $\mathrm{pJK} 10$, resulted in loss of pep $D$ complementing activity. Plasmid $\mathrm{pJK} 9$ arose from $\mathrm{pJK} 7$ by a spontaneous deletion which eliminated a $1.8 \mathrm{~kb}$ fragment including the unique BamHI site and the adjacent $\mathrm{SalI}$ site without affecting the functional integrity of the pep $D$ gene. Plasmid sizes and positions of restriction sites are drawn to scale. Hatched bars represent sequences originating from pBR322; portions of the ColE1 vector are marked by open bars; inserts of chromosomal $E$. coli DNA are drawn as heavy lines. The approximate positions of the genes phoE (Tommassen et al., 1982) and proBA (Hayzer, 1983) are indicated. Recognition sites for restriction enzymes are abbreviated as follows: B, BamHI; E, EcoRI; G, BglII; P, PstI; S, SalI. The restriction map of pLC44-11 was originally published by Hayzer (1983). It contains the positions of only four of altogether nine PstI sites.

destroyed by SalI cleavage of pLC44-11. Two of the SalI sites of pLC44-11 lie within the phoE and proBA coding regions (Fig. 1), which have been shown to be closely linked (Tommassen \& Lugtenberg, 1981). Therefore the third $S a / I$ site, flanking the ColE1 vector sequence, appeared to be the pepD inactivating site. 

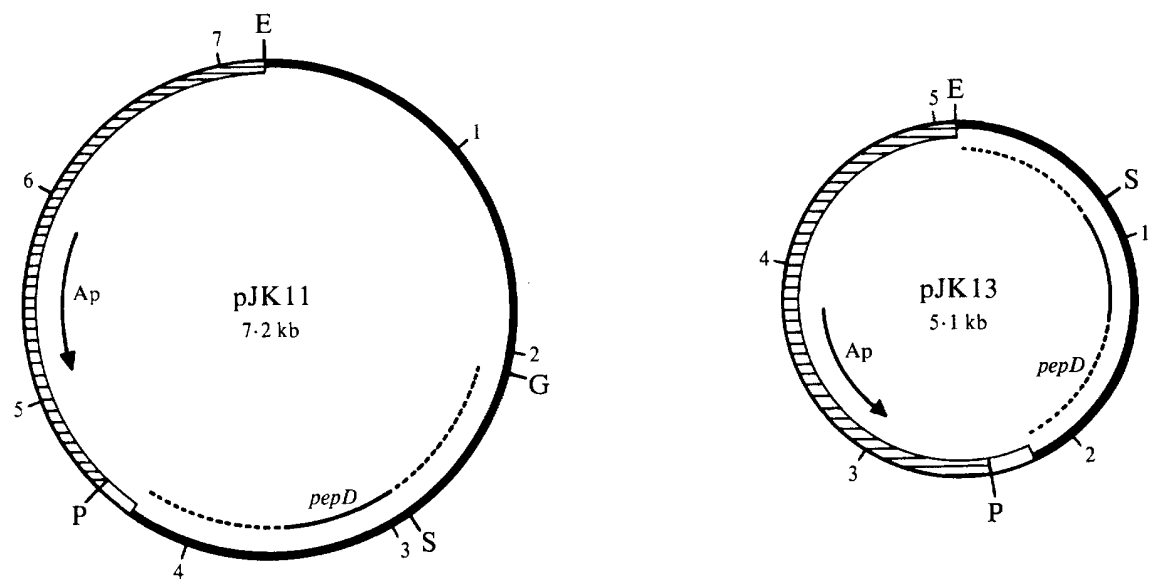

Fig. 2. Maps of the pUC18 hybrid plasmids pJK11 and pJK13. The vector pUC18 was cleaved at its unique PstI and EcoRI sites and ligated with Pst/EcoRI-digested plasmid pJK9 (see Fig. 1). After transformation of strain UK61 with the mixture the recombinant plasmid pJK11, containing the $4.5 \mathrm{~kb}$ PstI-EcoRI fragment of pJK9, was detected in carnosine-utilizing clones. Ligation of $P s t I / B g I I I$ cut pJK 9 with $P$ st $\mathrm{I} /$ Bam HI-digested pUC1 8 yielded the hybrid plasmid pJK13, which includes the $2.4 \mathrm{~kb}$ PstI-BglII fragment of pJK 9 and still carries a functional pepD gene. Inserts of chromosomal DNA, portions of the ColE1 plasmid and restriction sites are marked as in Fig. 1. Hatched bars represent plasmid sections originating from the vector $\mathrm{pUC18}$. The maximum pep $D$ coding region is indicated. Of this region, a segment of about $0.6 \mathrm{~kb}$, marked by an uninterrupted line, can be assigned definitely to the pep $D$ gene, assuming a $52 \mathrm{kDa}$ molecular mass for peptidase $\mathrm{D}$ (see Results and discussion). The scale given outside the maps is in $\mathrm{kb}$.

\section{Subcloning of the pepD gene}

In order to facilitate subsequent cloning experiments, strain UK61, which carries a deletion of the pep $D$ gene and, in addition, a $\operatorname{Tn} 10$ insertion in the gene his $G$, was constructed. Since, as in $S$. typhimurium, peptidase D proved to be the only peptidase able to cleave carnosine in $E$. coli, the presence of plasmid-encoded peptidase D in strain UK61 can be detected by simple complementation.

A pepD containing fragment of plasmid pLC44-11 was subcloned in the vector pBR322 and reduced in size as outlined in Fig. 1. The resulting plasmid, pJK9, was used to construct pJK11 and pJK13 (Fig. 2), which are pepD $D^{+}$derivatives of the small vector pUC18 (Norrander et al., 1983). Plasmid pJK 13 bears only a $2 \cdot 2 \mathrm{~kb}$ segment of genomic DNA, which corresponds to a coding capacity for approximately 730 amino acids. The localization of the pepD gene in the newly constructed plasmids was finally confirmed by insertional inactivation. A $1.45 \mathrm{~kb} S a l \mathrm{I}$ fragment, carrying the kanamycin resistance gene from Tn903 (Oka et al., 1981), was isolated from plasmid pUC4-K (Vieira \& Messing, 1982) and inserted into the unique SalI site of pJK13, which was suggested to lie within the pepD gene or its promoter. As expected, the resulting plasmid, pJK 13-K, did not confer peptidase D activity on strain UK61.

\section{Expression of the cloned pepD gene}

Transformation of the pep $D^{+}$strain AB1133 with the multicopy plasmid $\mathrm{pJK} 7$ increased the intracellular activity of peptidase $\mathrm{D}$ about 50 -fold. Because of this effect of gene dosage, peptidase $\mathrm{D}$ was expected to be detectable among the proteins of cells harbouring pepDcontaining plasmids.

Therefore plasmids pJK11 and pJK13 were expressed in the maxicell strain CSR603. As shown in Fig. 3, the pJK11 specific pattern contains three major proteins with molecular masses of 52,44 and $17 \mathrm{kDa}$ which are not encoded by the vector pUC18. Of these three additional bands, only the $52 \mathrm{kDa}$ band is also visible in the pattern of pJK13-encoded proteins. 


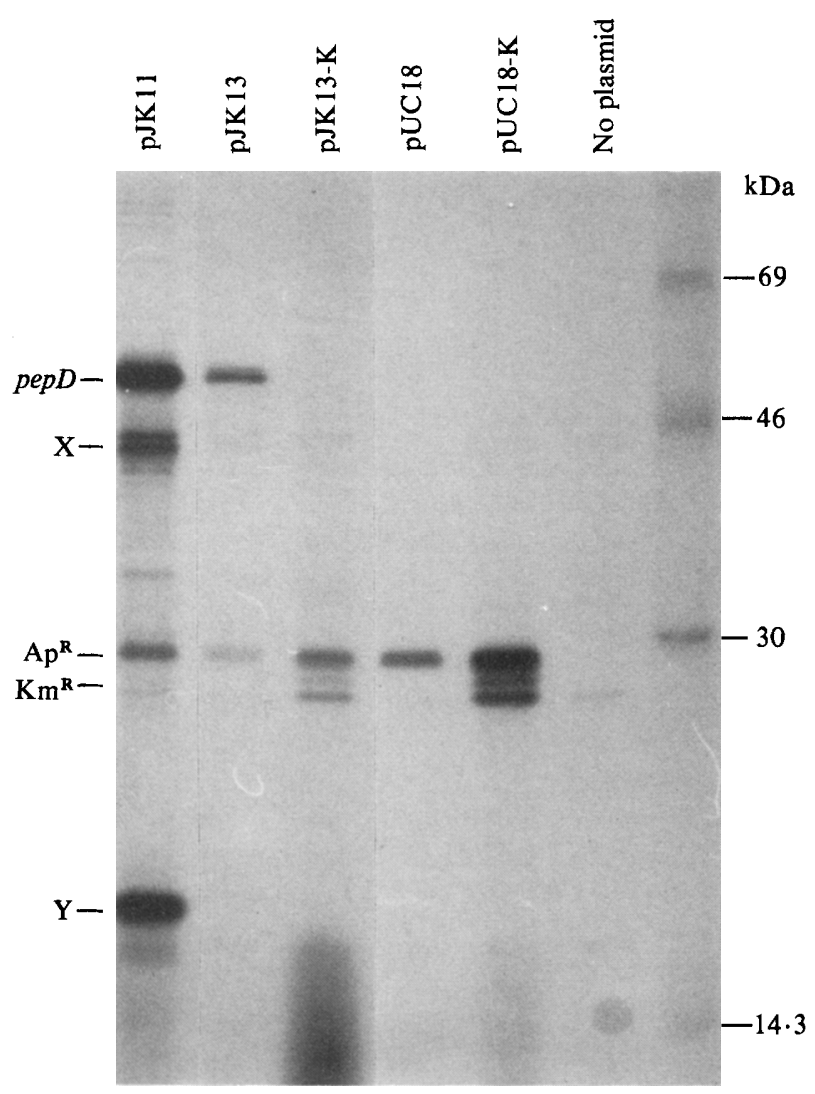

Fig. 3. Plasmid-directed protein synthesis in maxicells. ${ }^{35} \mathrm{~S}$-Labelled proteins synthesized in the maxicell strain CSR603 carrying the plasmids indicated were separated by SDS-PAGE. The pUC18-Kencoded proteins are $\beta$-lactamase $\left(\mathrm{Ap}^{\mathrm{R}}\right)$ and aminoglycoside phosphotransferase $\left(\mathrm{Km}^{\mathrm{R}}\right)$. Polypeptides with unknown or uncertain origin are denoted $\mathrm{X}$ and $\mathrm{Y}$. The sizes of protein standards are given.

Consequently, this $52 \mathrm{kDa}$ protein is likely to represent peptidase $\mathrm{D}$, particularly because pJK13, despite the small size of its insert, is still able to confer the PepD ${ }^{+}$phenotype on UK61 cells. Final evidence for this suggestion comes from the observation that insertion of the kanamycin resistance gene into the putative pepD coding region not only prevents complementation of pepD deletions by pJK $13-\mathrm{K}$, but also eliminates the $52 \mathrm{kDa}$ band from the pattern of pJK13-encoded proteins. Instead, a polypeptide with the electrophoretic mobility of Tn903-encoded aminoglycoside phosphotransferase $(27 \mathrm{kDa}$; Meagher et al., 1977) appears in the pJK13-K specific pattern. This was confirmed by maxicell expression of pUC18-K, which contains the pUC4-K derived kanamycin resistance gene inserted between the Sall sites of pUC18.

In addition to peptidase $\mathrm{D}$ and $\beta$-lactamase, plasmid $\mathrm{pJK} 11$ codes for at least two other polypeptides, called $\mathrm{X}$ and $\mathrm{Y}$, with molecular masses of about 17 and $44 \mathrm{kDa}$. These polypeptides are absent from the pJK13 specific protein pattern. Therefore, in combination with the mapping data of Hayzer (1983), the order of genes around the $6 \mathrm{~min}$ position of the $E$. coli map can be established to be proB-proA-phoE-xy-pepD.

One of the genes $x$ and $y$ appears to be gpt, which is closely linked with the proA locus (Holden et al., 1976). Indeed, plasmid pJK 11 was found to confer the ability to utilize guanine to the $g p t$ strain PC2086, in which de novo purine synthesis is blocked by a mutation in the pur $H$ gene. A definitive identification of the genes $x$ and $y$ might be facilitated with the aid of plasmid pJK 10 (Fig. 1), which carries no chromosomal genes except $x$ and $y$. 


\section{Molecular mass of peptidase $D$}

The molecular mass of the $S$. typhimurium peptidase D has been estimated to be $158 \mathrm{kDa}$ (Kirsh et al., 1978). To examine whether this value also applies to the $E$. coli enzyme, a cell free extract of strain PC1324 was subjected to gel filtration through Ultrogel AcA44. Active peptidase $\mathrm{D}$ eluted from this column with an apparent molecular mass of $100 \mathrm{kDa}$. In contrast, the molecular mass of denatured peptidase $\mathrm{D}$ as determined by SDS-PAGE of proteins synthesized in pJK13-containing maxicells is $52 \mathrm{kDa}$ (Fig. 3). This value agrees well with the $50 \mathrm{kDa}$ molecular mass of the largest pLC44-11-encoded polypeptide given in Neidhardt's gene-protein index (Neidhardt et al., 1983). As the coding of a protein of this size requires a nucleotide sequence of at least $1.4 \mathrm{~kb}$, at least $63 \%$ of the segment of genomic DNA included in the recombinant plasmid pJK13 (Fig. 2) is occupied by the pepD gene.

The discrepancy between the molecular masses of native and denatured peptidase D seems too large to be ascribed to inadequate calibration of columns or gels. Therefore, active peptidase $\mathrm{D}$ is possibly a dimer of about $100 \mathrm{kDa}$. As an alternative explanation, plasmid pJK $13 \mathrm{might}$ carry only a functional fragment of the original pep $D$ gene present on the $E$. coli chromosome.

A suitable explanation for the considerable difference in the sizes of the $E$. coli and $S$. typhimurium peptidase D might have to await the elucidation of the primary structures of these enzymes or of the corresponding genes. The isolation of the functional pepD gene from the E. coli chromosome and its integration into a convenient multicopy vector should now facilitate the sequencing of the gene as well as the purification and further characterization of its protein product. This might contribute to a more detailed understanding of the enzymology of peptidase $\mathrm{D}$ and of its role in peptide metabolism.

\section{REFERENCES}

ANRAKU, Y. (1964). A new cyclic phosphodiesterase having a $3^{\prime}$-nucleotidase activity from Escherichia coli B. Journal of Biological Chemistry 239, 34123419.

BACHMANN, B. J. (1983). Linkage map of Escherichia coli K-12. Microbiological Reviews 7, 180-230.

Blobel, G. \& Dobberstein, B. (1975). Transfer of proteins across membranes. Journal of Cell Biology 67, 835-851.

Bolivar, F., Rodriguez, R. L., Greene, P. J., BeTLACH, M. C., HeYNeCKER, H. L., BOYER, H. W., Crosa, J. H. \& FALKOW, S. (1977). Construction and characterization of new cloning vehicles. II. A multipurpose cloning system. Gene 2, 95-113.

Clarke, L. \& Carbon, J. (1976). A colony bank containing synthetic ColEl hybrid plasmids representative of the entire E. coli genome. Cell 9, 91-99.

Davis, B. D. \& Mingioli, E. S. (1950). Mutants of $E$. coli requiring methionine or vitamin B12. Journal of Bacteriology 60, 17-28.

Gutnic, D., Calvo, J. M., Klopotowski, T. \& Ames, B. N. (1969). Compounds which serve as the sole source of carbon or nitrogen for Salmonella typhimurium LT-2. Journal of Bacteriology 100, 215-219.

HAYZER, D. J. (1983). Sub-cloning of the wild-type pro $A B$ region of the Escherichia coli genome. Journal of General Microbiology 129, 3215-3225.

HAYzer, D. J. \& Leisinger, T. (1980). The geneenzyme relationships of proline biosynthesis in Escherichia coli. Journal of General Microbiology 118, 287-293.

HenRich, B., Lubitz, W. \& PlapP, R. (1982). Lysis of Escherichia coli by induction of cloned $\phi \times 174$ genes. Molecular and General Genetics 185, 493-497.

Holden, J. A., Harriman, P. D. \& Wall, J. D. (1976).
Escherichia coli mutants deficient in guanine-xanthine phosphoribosyltransferase. Journal of Bacteriology 126, 1141-1148.

Howard-Flanders, P., Boyce, R. P. \& Theriot, L. (1966). Three loci in Escherichia coli K-12 that control the excision of thymine dimers and certain other mutagen products from host or phage DNA. Genetics 53, 1119-1136.

Kirsh, M., Dembinski, D. R., Hartman, P. E. \& Miller, C. G. (1978). Salmonella typhimurium peptidase active on carnosine. Journal of Bacteriology 134, 361-374.

LAEMMLI, U. K. (1970). Cleavage of structural proteins during the assembly of the head of bacteriophage T4. Nature, London 227, 680-685.

LAZdunski, C., BusutTiL, J. \& LAZdunski, A. (1975). Purification and properties of a periplasmic aminoendopeptidase from Escherichia coli. European Journal of Biochemistry 60, 363-369.

LIVINGSTON, D. M. \& LeDER, P. (1969). Deformylation and protein biosynthesis. Biochemistry 8, 435-443.

Low, K. B. (1972). Escherichia coli K-12 F-prime factors, old and new. Bacteriological Reviews 36, 587607.

Maniatis, T., Fritsch, E. F. \& SambrooK, J. (1982). Molecular Cloning: A Laboratory Manual. Cold Spring Harbor, NY: Cold Spring Harbor Laboratory.

Meagher, R. B., Tait, R. C., Betlach, M. \& Boyer, H. W. (1977). Protein expression in $E$. coli minicells by recombinant plasmids. Cell 10, 521-536.

Miller, C. G. $(1975 a)$. Peptidases and proteases of Escherichia coli and Salmonella typhimurium. Annual Reviews in Microbiology 29, 485-504.

Miller, C. G. $(1975 b)$. Genetic mapping of Salmo- 
nella typhimurium peptidase mutations. Journal of Baceteriology 122, 171-176.

Miller, C. G. \& Green, L. (1981). Degradation of abnormal proteins in peptidase-deficient mutants of Salmonella typhimurium. Journal of Bacteriology 147 , 925-930.

Miller, C. G. \& Mackinnon, K. (1974). Peptidase mutants of Salmonella typhimurium. Journal of Bacteriology 120, 355-363.

Miller, C. G. \& Schwartz, G. (1978). Peptidasedeficient mutants of Escherichia coli. Journal of Bacteriology 135, 603-611.

Neidhardt, F. C., Vaughn, V., Phillips, T. A. \& BLoCH, P. L. (1983). Gene-protein index of Escherichia coli K-12. Microbiological Reviews 47, 231-284.

Norrander, J., Kempe, T. \& Messing, J. (1983). Construction of improved M13 vectors using oligodeoxynucleotide-directed mutagenesis. Gene 26, 101-106.

OKa, A., Sugisaki, H. \& TAKanami, M. (1981). Nucleotide sequence of the kanamycin resistance transposon Tn903. Journal of Molecular Biology 147, 217-226.

PINE, M. (1972). Turnover of intracellular proteins. Annual Reviews of Microbiology 26, 103-126.

PütTER, J. (1970). Peroxydasen. In Methoden der Enzymatischen Analyse, 2nd edn, vol. 2, pp. 648-653. Edited by $H$. U. Bergmeyer. Weinheim: Verlag Chemie.

ROSNER, R. (1972). Formation, induction and curing of bacteriophage P1 lysogens. Virology 49, 479-489.

SANCAR, A. \& RUPERT, C. S. (1978). Determination of plasmid molecular weights from ultraviolet sensitivities. Nature, London 272, 471-472.

SANCAR, A., HACK, A. M. \& RUPP, W. D. (1979). Simple method for identification of plasmid coded proteins. Journal of Bacteriology 137, 692-693.

Shugar, D. (1952). The measurement of lysozyme activity and the ultra-violet inactivation of lysozyme. Biochimica et biophysica acta 8, 302-309.

Simmond, S. \& FruTon, J. S. (1949). The utilization of amino acids and peptides by mutant strains of Escherichia coli. Journal of Biological Chemistry 180, 635-646.

Sussman, A. J. \& Gilvarg, C. (1971). Peptide transport and metabolism in bacteria. Annual Reviews in Biochemistry 40, 397-408.

Tommassen, J. \& LugTenberG, B. (1981). Localization of phoE, the structural gene for outer membrane protein e in Escherichia coli K12. Journal of Bacteriology 147, 118-123.

Tommassen, J., Overduir, P., LugtenberG, B. \& Bergmans, H. (1982). Cloning of phoE, the structural gene for the Escherichia coli phosphate limitation-inducible outer membrane pore protein. Journal of Bacteriology 149, 668-672.

VIEIRA, J. \& MESSING, J. (1982). The pUC plasmids, an M13mp7-derived system for insertion mutagenesis and sequencing with synthetic universal primers. Gene 19, 259-268.

Yen, C., Green, L. \& Miller, C. G. (1980). Degradation of intracellular protein in Salmonella typhimurium peptidase mutants. Journal of Molecular Biology 143, 21-33. 